\title{
Variability of composition of essential oil and coumarin compounds of Angelica archangelica L.
}

\author{
ANNA FORYCKA*, WALDEMAR BUCHWALD
}

\author{
Department of Botany, Breeding and Agricultural Technology of Medicinal Plants \\ Institute of Natural Fibres and Medicinal Plants \\ Kolejowa 2 \\ 62-064 Plewiska \\ *corresponding author: e-mail: anna.forycka@iwnirz.pl
}

\section{Summary}

\begin{abstract}
The medicinal and culinary properties of Angelica archangelica L. have been known and valued since the Middle Ages. Ingredients of essential oil and coumarins found in this plant are to a large degree responsible for its pharmacological activity. This study is a review of the literature of the most important biologically active compounds present in herbal raw materials: root (rhizome with roots) and angelica fruits. Research shows that the content of individual compounds of the essential oil and coumarin fraction is variable, which may point to a large intraspecific variation. Therefore, these compounds may be good markers for identifying taxa or chemotypes in chemotaxonomic research valuable for the herbal medicine and pharmaceutical industry.
\end{abstract}

Key words: Angelica archangelica, essential oil, coumarins, furanocoumarins, chemical composition, chemotaxonomy

Słowa kluczowe: Angelica archangelica, olejek eteryczny, kumaryny, furanokumaryny, skład chemiczny, chemotaksonomia

\section{INTRODUCTION}

In modern phytotherapy, the demand for precise quantitative and qualitative data concerning herbal raw material used in the production of medicines has been rising, mainly due to restrictive control of the quality, safety and biological activity $[1,2]$. Despite the limitations of the analytical methods, the description and chemical characterization of variability within the species treated and used as a medicinal plant should be complemented. Material from the same species may vary significantly in 
composition of secondary metabolites [3].

The genus Angelica (Apiaceae family) is a large and taxonomically complex genus consisting of many (90-110) species and varieties, among which over 60 species are widely recognized as medicinal plants [4]. It is considered to be a highly polymorphic group due to huge anatomical diversity of fruit and leaf morphology [5]. Due to that fact is very difficult to distinguishing between Angelica taxa [6].

One of the most important representatives of this genus is the Angelica archangelica species, a medicinal and aromatic plant native to Europe, with a long history of use both for medicinal purposes and as a vegetable [7]. Its dried root and essential oil are used for the production of liqueurs, perfumes and spice extracts. The medicinal raw material mentioned in Europaean Pharmacopoeia 9.0 [8] is the angelica root (rhizome with roots) containing essential oil and coumarins. Flavonoids, organic acids, steroids, saponins, alkaloids, simple sugars and fats are also present in the raw material [9]. It can effectively regulate digestive system, stimulate immune system and improve resistance of the nervous system in anxiety and dementia [10-13]. It also exhibits bactericidal, fungicidal and anti-inflammatory effects [14-16]. The in vitro and in vivo extracts from the root of angelica have antitumor potential against breast cancer cells [17]. The fruits of angelica were previously used in smaller scale. Nowadays, they are considered to be a rich source of coumarin compounds with potentially wide range of applications in various therapeutic purposes $[3,18-20]$.

Currently, two taxa of $A$. archangelica $(A a)$ are distinguished as subspecies: subsp. archangelica (former Archangelica officinalis Hoffm.) and subsp. litoralis (Fies) Thell. (previously Archangelica litoralis Fries) [21].

The natural habitat of the first subspecies is the mountainous areas of Europe, the Arctic, the Caucasus and the Himalayas [22], while subsp. litoralis is found on the sea coasts and river banks, in moist forests and thickets, as well as in the meadows of northern Europe and Scandinavia [23]. Angelica is cultivated as a medicinal and aromatic plant in northern, central and western Europe. This species spreads and as a synanthropic plant, occupies new areas [24-29]. The plants of both taxa differ in their smell and taste, which indicates intraspecific variability in the chemical composition. Aa subsp. litoralis is characterized by sharper smell and taste than $A a$ subsp. archangelica, some authors consider it to be inedible [30]. However, two subspecies are generally not separated in phytotherapy, due to morphological differences that are difficult to notice. In the literature, there are varieties of $A$. archangelica subsp. archangelica: var. archangelica, var. norvegica (currently included in var. archangelica), var. sativa (Mill.) Rikli, var. decurrens (Lebed.) Weinert [31]. Their morphological criteria are not always specified. Occurrence of var. archangelica and var. sativa concerns Europe, while var. decurrens are distinguished in the Asian part of angelica range (eastern Siberia). Pharmacologic and chemotaxonomic studies as well as phytochemical discoveries are helpful in solving taxonomic problems encountered by taxonomists [32]. They often allow not only to differentiate taxa that are difficult to mark on the basis of morphological criteria, but also to identify the chemical phenotypes, which can be particularly valuable in the case of plants used in herbal and pharmaceutical industries or as food. Studies indicate that the level of secondary metabolites, which is influenced by genetic regulation, may vary within the species depending on geographic origin [33-35].

In this context, the analysis of intraspecific variability of angelica, in terms of main secondary metabolites, such as essential oils and coumarins accumulated in great amounts in the roots and fruit of this species, seems to be interesting.

It should be taken into account that the chemical composition of the analyzed raw material is influenced by various parameters, such as genetic and environmental factors, the age of the plant and the type of organ tested, as well as the harvesting method, raw material treatment and analytical techniques used.

\section{CHEMICAL CHARACTERISTICS OF ESSENTIAL OIL OF ANGELICA}

Essential oil is obtained from raw material using classic and advanced techniques. The most important and most commonly used methods of oil isolation are steam distillation and hydrodistillation, recently also supercritical fluid extraction (SFE). For qualitative analysis of the oil and isolation of its compounds gas chromatography coupled with mass spectrometry (GC-MS) is widely used.

Essential oils are multi-compound mixtures of terpenoid hydrocarbons including mono-, sesquiand diterpene compounds, non-terpenoid hydrocarbons and their oxygenated derivatives [36]. One oil can contain several dozen different compounds. In most oils one main ingredient or a mixture of several main ingredients gives the fragrance to the 
whole oil. Roots and fruits are particularly rich in oils. The main ingredients found in angelica essential oil are listed in table 1.

The presence and proportions of individual ingredients determine the aromatic properties of the oil. For example, high content of $\beta$-phellandrene gives the peppery-minty and slightly citrus aroma [37]. High concentrations of $\alpha$ - and $\beta$-pinen are responsible for the terpene fragrance. The presence of 15-pentadecanolide in the oil is manifested by a characteristic "musky" aroma [38]. Furthermore, some substances such as oxidized 3-carene, limonene and $\alpha$-pinene derivatives can cause allergic symptoms [39] and therefore are not desirable in large amounts in medicinal raw material.

\section{Root}

Angelica root contains from 0.2 to $0.5 \%$ essential oil [40]. More than 62 to 100 compounds were identified in the chemical composition of the oil with the use of new analytical methods [41-43].

The largest fraction of the essential oil from angelica root are hydrocarbon monoterpens $( \pm 60-88 \%$ of aromatic compounds of the oil) and oxygenated compounds $[38,44,45]$. A significant fraction of the oil are sesquiterpene hydrocarbons, which account for $8 \%$ in steam distillation [42] and for $10-24.7 \%$ in Soxhlet extracts [46]. This hydrocarbon group consisted of numerous compounds that were detected in small amounts. Other compounds at higher concentrations included lactones of 13-hydroxytridecanoic acid and 15-hydroxypentadecanoic acid, which are among the typical fragrance compounds found in angelica. The content of 13-tridecanolide ranged from 2 to $2.7 \%$, and 15 -pentadecanolide from 3 to $5.9 \%$ [46]. Coumarins were usually found in small amounts in the oil.

The characteristic feature of monoterpenic hydrocarbons is the clear dominance of one of the compounds. The most commonly found monoterpenes, such as $\alpha$-pinene, $\alpha$ - and $\beta$-phellandrene, 3 -carene and limonene, are considered to be important speciesspecific compounds [47]. Angelica $\beta$-phellandrene was mentioned as the main compound occurring both in the root and fruits [48].

Studies on the essential oil of angelica root of European origin have shown diversity in its composition depending on the area of occurrence and the variety (tab. 1). The biggest differences concerned $\beta$-phellandrene level. Several types of oil can be distinguished, according to the main ingredient, in which $\beta$-phellandrene, $\alpha$-pinene, sabinene and myrcene are the dominating ones. Essential oil from plant roots growing in Scandinavia usually contains $\beta$-phellandrene or $\beta$-phellandrene as a main ingredient along with $\alpha$-pinene, which constitute about $50 \%$ of the monoterpenes fraction $[38,42$, $46,49]$. The highest values of $\beta$-phellandrene were found in raw material obtained from northern $\mathrm{Eu}-$ rope (Finland, Norway), where this type of oil is the most common one. As the dominant compound of the root, $\beta$-phellandrene was also found in Central and Eastern Europe, but concentrations of this compound were lower [40]. In most materials from Central, Southern and Eastern Europe, the main compound of the oil in angelica root was $\alpha$-pinene $[14,43,50-53]$. Sabinene was found in large quantities in raw material from western and northern parts of Finland $[45,54]$. In the root of cultivated var. sativa, sabinene was the dominant compound of the oil [49]. In one Finnish population, the dominant compound of the isolated oil was myrcene [45]. A significant substance among main oil compounds was also 3-carene. It was often present in high concentration as the second or third most important essential oil compound, and in some cases as a main compound [55]. It has been observed that populations of different origins may differ in the presence or absence of 3-carene [54]. Moreover, there is a high diversity of chemical oil composition among aforementioned angelica taxa. Forsén [38] assessed the composition and content of essential oil of two angelica varieties - var. norvegica (now var. archangelica) and var. sativa, which originate from cultivation in southern Finland. Both forms of angelica had different flavors, which was confirmed by chemical analysis. Varieties differed mainly in the relative amount of $\beta$-phellandrene, $\alpha$-pinene, limonene and $p$-cymene. The main compound of var. norvegica was $\beta$-phellandrene (24.78-28.18\%), followed by $\alpha$-pinene $(14.52-18.14 \%)$ and $\alpha$-phellandrene (9.61-14.35\%), while in var. sativa $\alpha$-pinene (21.12$31.19 \%$ ) was a dominant, followed by $\beta$-phellandrene $(13.88-16.03 \%)$ and $\alpha$-phellandrene $(2.38-10.04 \%)$. High concentrations of limonene and $p$-cymene have also been reported, although in var. sativa levels of limonene and $p$-cymene were slightly higher than in var. norvegica.

Similar comparative studies were conducted by Kerrola et al. [49] for var. archangelica, growing wild in Finland and var. sativa coming from Hungary. Volatile substances were isolated from the roots of plants cultivated in two locations in the south and north Finland. The raw material was subjected to Soxhlet extraction, gas 
Table 1.

Major constituents and composition of essential oil [\%] from Angelica archangelica

\begin{tabular}{|c|c|c|c|}
\hline $\begin{array}{c}\text { Part of } \\
\text { plant }\end{array}$ & Origin & Major compounds [\%] & References \\
\hline Root & Germany/commercial sample & $\begin{array}{l}\alpha \text {-pinene (24\%); limonene (13.2\%); 3-carene (10.1\%); } \beta \text {-phellandrene (10\%); p-cymene } \\
(9.8 \%) ; \alpha \text {-phellandrene }(7.6 \%)\end{array}$ & [43] \\
\hline Root & Germany/commercial sample & $\beta$-phellandrene; $\mathrm{p}$-cymene; $\alpha$-pinene; sabinol; 3-carene & {$[42]$} \\
\hline Root & $\begin{array}{l}\text { Finland; Aa subsp. archangelica var. } \\
\text { archangelica }\end{array}$ & $\begin{array}{l}\beta \text {-phellandrene (24.78-28.18\%); } \alpha \text {-pinene (14.52-18.14\%); } \alpha \text {-phellandrene }(9.61-14.35 \%) ; \\
\text { limonene (5.81-7.09\%); } p \text {-cymene }(3.26-5.32 \%)\end{array}$ & [38] \\
\hline Root & $\begin{array}{l}\text { Finland; Aa subsp. archangelica var. } \\
\text { sativa }\end{array}$ & $\begin{array}{l}\alpha \text {-pinene }(25.24-30.51 \%) ; \beta \text {-phellandrene }(14.04-14.58 \%) ; \alpha \text {-phellandrene }(9.53-10.04 \%) ; \\
\text { limonene }(8.44-8.54 \%) ; p \text {-cymene }(5.20-6.25 \%)\end{array}$ & [38] \\
\hline Root & $\begin{array}{l}\text { Finland; Aa subsp. archangelica var. } \\
\text { sativa }\end{array}$ & $\begin{array}{l}\alpha \text {-pinene }(21.12-31.19 \%) ; \beta \text {-phellandrene }(13.88-16.03 \%) ; \text { limonene }(10.83-11.53 \%) ; \\
\text { p-cymene }(8.33-11.30 \%) ; \text { myrcene }(3.15-4.62 \%)\end{array}$ & [38] \\
\hline Root & $\begin{array}{l}\text { Finland/Finnish Lapland; Aa subsp. } \\
\text { archangelica var. archangelica }\end{array}$ & $\begin{array}{l}\beta \text {-phellandrene }(12.3-15.4 \%) ; \alpha \text {-pinene }(2.2-9.1 \%) ; 15 \text {-pentadecanolide }(3.0-4.1 \%) \text {; sabinene } \\
(3.3-3.9 \%) ; 3 \text {-carene }(0.2-3.5 \%)\end{array}$ & [49] \\
\hline Root & $\begin{array}{l}\text { Finland/cultivation Aa subsp. } \\
\text { archangelica var. sativa }\end{array}$ & $\begin{array}{l}\text { sabinene (5.9-14.8\%); } \alpha \text {-pinene }(4.8-9.9 \%) ; 15 \text {-pentadecanolide }(4.2-5.9 \%) ; 3 \text {-carene }(2.7- \\
6.7 \%) ; \beta \text {-phellandrene }(2.1-4.0 \%) ; \text { limonene }(1.9-4.6 \%)\end{array}$ & [49] \\
\hline Root & Island & $\alpha$-pinene (65.3\%); limonene (5.3\%); $\beta$-phellandrene (5.3\%); myrcene (4.2\%); 3-carene (4.2\%) & [45] \\
\hline Root & Norway & $\begin{array}{l}\beta \text {-phellandrene }(28.3-41.9 \%) ; \alpha \text {-pinene }(17.7-22.9 \%) ; 3 \text {-carene }(6.0-15.3 \%) \text {; myrcene (5.4- } \\
13.3 \%) \text {; limonen }(5.0-7.1 \%)\end{array}$ & {$[45]$} \\
\hline Root & Finland/Kemi Lapland & $\begin{array}{l}\beta \text {-phellandrene (12.4-49.3\%); } \alpha \text {-pinene (8.4-25.1\%); sabinene (6.8-25.5\%); myrcene (7.3- } \\
\text { 19.4\%); limonene (2.6-6.2\%) }\end{array}$ & {$[45]$} \\
\hline Root & Finland/Inari Lapland & $\begin{array}{l}\beta \text {-phellandrene (25.5-45.2\%); } \alpha \text {-pinene (11.6-29.2\%); myrcene (6.0-24.4\%); sabinene (0.8- } \\
15.9 \%) ; 3 \text {-carene }(2.8-15.0 \%) ; \text { limonene }(4.4-6.8 \%)\end{array}$ & {$[45]$} \\
\hline Root & Finland/Inari Lapland & $\begin{array}{l}\alpha \text {-pinene }(29.2-46.1 \%) ; \beta \text {-phellandrene }(12.5-28.8 \%) \text {; myrcene }(8.7-16.1 \%) \text {; limonene (6.1- } \\
6.6 \%) \text {; sabinene }(3.2-5.6 \%) ; 3 \text {-carene }(3.8 \%)\end{array}$ & {$[45]$} \\
\hline Root & Finland/Somerniemi & $\begin{array}{l}\text { myrcene }(41.3-46.8 \%) ; \beta \text {-phellandrene }(24.0-25.0 \%) ; \alpha \text {-pinene }(10.3-12.6 \%) ; \text { limonene }(6.7 \text { - } \\
6.9 \%) ; p \text {-cymene }(5.3-9.2 \%)\end{array}$ & [45] \\
\hline Root & Finland/West\&North Lapland & $\alpha$-pinene (19-42\%); sabinene (21-28\%); 3-carene (0-22\%) & [54] \\
\hline Rroot & $\begin{array}{l}\text { Greenland and Faroe Island/ } \\
\text { cultivation in Sweden }\end{array}$ & $\alpha$-pinene; $\alpha$-phellandrene; tridecanolide; pentadecanolide & {$[44]$} \\
\hline Root & $\begin{array}{l}\text { France/French Massive Central; } \\
\text { tubers/rootlets/roots }\end{array}$ & $\begin{array}{l}\alpha \text {-pinene }(22.21-28.65 \%) ; 3 \text {-carene }(15.80-17.23 \%) ; \beta \text {-phellandrene }(6.68-8.35 \%) ; \text { limonene } \\
(7.05-8.39 \%) ; p \text {-cymene }(5.99-6.58 \%)\end{array}$ & [53] \\
\hline Root & $\begin{array}{l}\text { Denmark; Aa subsp. archangelica } \\
\text { var. norvegica }\end{array}$ & 3-carene (13.0\%); $\alpha$-pinene (9.8\%); limonene (7.3\%) & [55] \\
\hline Rroot & Romania & $\begin{array}{l}\alpha \text {-pinene }(16.66 \%) \text {; limonene }(13.12 \%) ; \alpha \text {-phellandrene }(11.27 \%) ; \beta \text {-phellandrene }(8.92 \%) \text {; } \\
\text { 3-carene }(8.69 \%) ; \text {-cymene }(5.56 \%) \text {; t-ocimene }(5.43 \%)\end{array}$ & [41] \\
\hline $\begin{array}{l}\text { Root } 1-2 \\
\mathrm{~mm}\end{array}$ & Italy & $\begin{array}{l}\alpha \text {-pinene (23.89\%); 3-carene (3.41\%); limonene (2.43\%); myrcene (2.13\%); germacrene D } \\
(2.1 \%)\end{array}$ & {$[52]$} \\
\hline $\begin{array}{l}\text { Root 3-4 } \\
\mathrm{mm}\end{array}$ & Italy & $\begin{array}{l}\alpha \text {-pinene (35.7\%); sabinene (7.0\%); 3-carene (4.6\%); limonene (3.6\%); } \beta \text {-phellandrene (2.3\%); } \\
\text { myrcene (1.5\%); germacrene D }(1.5 \%)\end{array}$ & {$[52]$} \\
\hline $\begin{array}{l}\text { Root }>5 \\
\mathrm{~mm}\end{array}$ & Italy & $\begin{array}{l}\alpha \text {-pinene (32.69\%); 3-carene (17.07\%); limonene (6.59\%); myrcene (5.87\%); } \alpha \text {-phellandrene } \\
\text { (3.74\%); } \beta \text {-phellandrene (3.43\%) }\end{array}$ & [52] \\
\hline Root & Lithuania/Svecionys District & $\alpha$-pinene (15.7-19.1\%); 3-carene (15.4-16.9\%); limonene (8.0-9.2\%); sabinene (5.0-7.5\%) & [40] \\
\hline Root & Lithuania/Prienai District & $\begin{array}{l}\alpha \text {-pinene (19.4-20.8\%); } \beta \text {-phellandrene (13.5-15.4\%); 3-carene (13.2-14.2\%); } \alpha \text {-phellandrene } \\
(8.0-9.1 \%)\end{array}$ & [40] \\
\hline Root & Lithuania/Vilnius Distrisct & $\begin{array}{l}\beta \text {-phellandrene (13.8-18.5\%); } \alpha \text {-pinene }(11.4-15.0 \%) ; 3 \text {-carene }(10.8-11.9 \%) ; p \text {-cymene } \\
(6.8-10.6 \%) ; \alpha \text {-phellandrene }(5.9-8.6 \%)\end{array}$ & [40] \\
\hline Root & Lithuania/cultivation & $\begin{array}{l}\beta \text {-phellandrene (15.1\%); } \alpha \text {-pinene (11.2\%); 3-carene (10.6\%); p-cymene (6.8\%); } \\
\alpha \text {-phellandrene (5.4\%) }\end{array}$ & [40] \\
\hline Root & Italy/cultivation & $\alpha$-pinene (21.3\%); 3-carene (16.5\%); limonene (16.4\%); $\alpha$-phellandrene (8.7\%) & [14] \\
\hline Root & Serbia & $\alpha$-pinene (29.7\%); 3-carene (14.2\%); $\beta$-phellandrene + limonene $(13.2 \%)$ & [50] \\
\hline Fruit & Poland & $\beta$-phellandrene; copaene; humulene, $\beta$-bisabolene & [57] \\
\hline Fruit & Poland/commercial sample & $\begin{array}{l}\beta \text {-phellandrene (59.4\%); } \alpha \text {-pinene (2.9\%); } \alpha \text {-phellandrene (2.3\%); } \alpha \text {-humulene (3.3\%); } \\
\text { germacrene D (3.1\%) }\end{array}$ & [58] \\
\hline Seeds & Finland/West Lapland & $\beta$-phellandrene (82.1\%); $\alpha$-pinene (5.5\%); $\alpha$-phellandrene (3.8\%); myrcene $(3.4 \%)$ & [54] \\
\hline Seeds & Finland/East Lapland & $\beta$-phellandrene (66.4\%); sabinene (11.3\%); $\alpha$-pinene (8.7\%); myrcene $(7.3 \%)$ & [54] \\
\hline Seeds & Finland/North Lapland & $\begin{array}{l}\beta \text {-phellandrene (74.0\%); } \alpha \text {-pinene (9.4\%); sabinene (5.4\%); } \alpha \text {-phellandrene (4.3\%); myrcene } \\
(4.0 \%)\end{array}$ & [54] \\
\hline Fruit & Island & $\beta$-phellandrene (37.8\%); $\alpha$-pinene (28.9\%); $\alpha$-phellandrene $(1.7 \%)$ & {$[48]$} \\
\hline Fruit & Island & $\alpha$-pinene (41.4\%); sabinene (2.1\%); $\beta$-pinene (1.7\%); $\beta$-phellandrene $(0.0 \%)$ & [48] \\
\hline Fruit & Lithuania/Svencionys District & $\begin{array}{l}\beta \text {-phellandrene (43.8\%); } \alpha \text {-pinene (9.1\%); germacrene D (3.0\%); } \alpha \text {-phellandrene }(2.7 \%) \text {; } \\
\text { myrcene (2.5\%); sabinene (2.5\%) }\end{array}$ & [59] \\
\hline Fruit & Lithuania/Prienai District & $\begin{array}{l}\beta \text {-phellandrene (33.6\%); } \alpha \text {-pinene (12.8\%); } \alpha \text {-phellandrene (7.4\%); sabinene (4.6\%); } \beta \text {-pinene } \\
(3.7 \%) ; \text { myrcene }(2.0 \%)\end{array}$ & [59] \\
\hline Fruit & Lithuania/Vilnius District & $\begin{array}{l}\beta \text {-phellandrene (63.4\%); } \alpha \text {-pinene (4.2\%); sabinene (3.3\%); } \alpha \text {-phellandrene (2.6\%); myrcene } \\
(2.0 \%)\end{array}$ & [59] \\
\hline Fruit & $\begin{array}{l}\text { France/Le Havre, Thiais/cultivation; } \\
\text { Aa subsp. archangelica var. sativa }\end{array}$ & $\beta$-phellandrene (64.9-65.8\%); $\alpha$-pinene (2.3-6.6\%); myrcene $(2.4-3.2 \%)$ & [56] \\
\hline Fruit & France/Fortvert; Aa subsp. litoralis & $\beta$-phellandrene (76.0\%); $\alpha$-pinene (4.2\%); $\alpha$-phellandrene $(3.4 \%)$ & [56] \\
\hline
\end{tabular}


chromatography and gas chromatography-mass spectrometry. Studies on root have clearly shown different compositions of volatile substances in var. archangelica and var. sativa which confirms the results obtained by Forsén [38]. The most abundant compound in the roots of var. archangelica was $\beta$-phellandrene (12.3$15.4 \%)$, while in var. sativa - sabinene (5.9-14.85\%). The $\alpha$-pinene, 15 -pentadecanolide and 3-carene were a significant part in the chemical composition of both forms.

Geographic diversity of the composition of the oil from angelica root growing in Northern Europe was analyzed by Ojala et al. [45]. They examined the plants from 15 populations from Finland, Iceland and Norway, grown in identical conditions. The main compounds were $\beta$-phellandrene and $\alpha$-pinene, followed by sabinene, limonene, myrcene, $p$-cymene and 3-carene. Among those populations, sample from Iceland stood out by the very high concentration of $\alpha$-pinene (65.3\%). In populations of Finland and Norway differences in the composition of essential oils were observed, according to the latitude gradient. Besides $\beta$-phellandrene, which was the main ingredient, Finnish populations from the north (Inari Lapland) contained relatively high amounts of sabinene, while Norwegian - low levels of myrcene and $p$-cymene. One of Finnish populations from the southern part of Inari Lapland was characterized by a high $\alpha$-pinene content. The population from southern Finland (Somerniemi) differed from the northern one in high concentration of myrcene, which was the dominant compound of the oil.

Geographical differences were also found in the content of 3-carene - the level of this compound was the lowest in the population of the south of Finland $(0-0.2 \%)$, the highest in populations harvested from northern Finland and Norway (to 15.3\%).

The study of essential oil from angelica plants growing wild in Lithuania was carried out by Nivinskiene et al. [40]. They analyzed the chemical composition of the oil from 12 root samples collected from three locations in the natural state (Svencionys, Prienai and Vilnius district), which were compared with the roots from the cultivation in Vilnius. At two sites (Svencionys and Prienai) the main compound of the oil was $\alpha$-pinene, whose level ranged from $15.7 \%$ to $20.8 \%$. The content of other ingredients varied. At one of the sites (Svencionys) the samples were found to have high concentration of 3-carene, limonene and sabinene. In the second site (Prienai), apart from $\alpha$-pinene, $\beta$-phellandrene, 3 -carene and $\alpha$-phellandrene had high concentrations. The biggest difference in the proportion of the main compounds was observed in the third site (Vilnius district), where the compound was $\beta$-phellandrene in concentrations $13.8-18.5 \%$, and only the next compound $\alpha$-pinene, 3 -carene and cymene. Angelica root oil from cultivation contained $\beta$-phellandrene $(15.1 \%)$ as the dominant compound.

The content and composition of angelica oil in individual stages of plant development were assessed by Ojala et al. [45]. The level of essential oil in the roots harvested in the second and third years of plant vegetation was $0.3-0.8 \%$ d.m. and $0.27-1.1 \%$ d.m., respectively. Despite the quantitative differences in subsequent years, the composition of oils in the tested samples did not change.

Chalchat and Garry [53] analyzed the chemical composition of underground parts of plants of angelica used as a raw material: rootlets, roots and tubers. All parts of the raw material had a similar oil composition characterized by a high content of $\alpha$-pinene (over 30\%) and a low content of $\beta$-phellandrene (1.3\%). Higher amount of oil was obtained from roots $(0.45 \%)$ than from tubers or rootlets $(0.17-0.33 \%)$.

Pasqua et al. [52] compared the accumulation of essential oils at various stages of development of angelica roots. The amount of oils increased with the degree of root differentiation and reached the highest level in roots thicker than $5 \mathrm{~mm}$. Regardless of the degree of root development, the dominant compound was $\alpha$-pinene (23.89-35.7\%). The level of individual compounds changed in subsequent stages of development. A correlation was found between the plant development stage and the content of 3-carene, whose level increased in successive degrees of root differentiation [38].

It was found that the chemical composition of the raw material varies depending on the form of storage. Nivinskiene et al. [51] studied the oil of angelica root stored unshreeded, ground or unground for 2.5 months. In the unshreded yield monoterpenes hydrocarbons (66.7-72.5\%) were the largest part, and the main compound of the oil was $\alpha$-pinene (15.7-19.4\%). Important ingredients were, depending on the plant origin, 3 -carene, limonene or $\beta$-phellandrene. The amount of monoterpene hydrocarbons in the root stored in powdered form decreased in relation to the raw material - it evaporated in about $70 \%$, and the content of the main compounds ( $\alpha$-pinene, 3-carene and limonene) decreased 3.5-4 times.

Comparison of the most commonly used extraction methods, such as steam distillation and hydrodistillation, indicate a similar composition and proportions of 
ingredients of the oil [53].

The SFE method has been optimized for the isolation of volatile substances from angelica root. For this purpose, Nykänen et al. [42] used supercritical $\mathrm{CO}_{2}$ extracts obtained in various conditions (temp. $40^{\circ} \mathrm{C}$, pressure $80-400$ bar). Overall volatile compound yield and composition varied depending on the pressure used: $0.13-0.55 \%$ oil was obtained, with the highest monoterpenoid content acquired at 100 bar. It has been shown that, compared to the traditional method of steam distillation, the SFE method was more efficient, with different volatile compound profiles under different extraction conditions.

The advantage of the SFE method, compared to steam distillation or liquid solvent extraction, is that it does not cause significant thermal degradation of unstable compounds, it does not create artifacts and solvent contamination, which results in a higher quality of oil [41].

\section{Fruit}

The content of essential oil in the fruit ranged from 0.01 to $2.0 \%$ [48]. The highest oil content was achieved in fully riped fruits [56].

Gawdzik et al. [57] analyzed the fractions of angelica essential oil obtained from the fruit by SFE with carbon dioxide at varying temperatures. The following oils compounds, typical for angelica, were identified in particular fractions: $\beta$-phellandrene, humulene, $\beta$-bisabolene.

Studies of angelica oil in terms of geographic variability revealed significant differences in chemical composition. Holm et al. [54] examined seed extracts from angelica collected from sites in the northern, eastern and western parts of Lapland (northern Finland). The seed oil was dominated by $\beta$-phellandrene, which accounted for over $60 \%$ of all volatile compounds. The content of other ingredients depended on the plant origin. Among the compounds of great importance for the composition of the oil were $\alpha$-pinene, sabinene, myrcene and $\alpha$-phellandrene. Despite high variability in monoterpenes, and composition between individual samples, a certain pattern of geographical differences was observed. The concentration of $\beta$-phellandrene in the extracts was higher in the west than in the east. $\beta$-phellandrene level was highest for seed samples from the north. Seed extracts from eastern Lapland, in turn, were notable for high concentration of sabinene and myrcene, as compared to other regions.

Samples of angelica fruits originating from Iceland, despite the lack of clear morphological differences between plants and their fruits, varied in content of essential oil as well as its chemical composition [48]. Two different types of oils have been identified, characterized by the presence or absence of $\beta$-phellandrene. In samples with a higher content of essential oil (0.32-0.51\%) a dominant compound was $\beta$-phellandrene $(37.8-55.2 \%)$. In the sample with low oil content $(0.17 \%)$, no $\beta$-phellandrene was found, while the main compound was $\alpha$-pinene (41.4\%).

Wolski et al. [58] analyzed the essential oil of angelica grown in Poland. The most important compounds of the fruit oil were monoterpenes, primarily $\beta$-phellandrene (59.4\%), $\alpha$-pinene (2.9\%) and $\alpha$-phellandrene (2.3\%). Sesquiterpenes such as $\alpha$-humulene, $\alpha$-copaene and germacrene $\mathrm{D}$ were also abundant.

Nivinskiene et al. [59] examined the composition of essential oils from the fruit from three angelica sites growing wild in Lithuania. These tests represented a chemotype with predominant $\beta$-phellandrene (33.6-63.4\%), where $\alpha$-pinene was also present in large quantities (4.2-12.8\%). Third site, depending on the origin of the sample, was occupied by $\alpha$-phellandrene, germacrene D or sabinene. Essential oils of fruit from one sample from Lithuania, Poland, and Finland (West Lapland) were similar in terms of the main compounds ( $\beta$-phellandrene, $\alpha$-pinene and $\alpha$-phellandrene). However, in other sample from Lithuania the base oil composition ( $\beta$-phellandrene, $\alpha$-pinene, sabinene, $\alpha$-phellandrene and myrcene) was the same as in the sample from Finland (North Lapland).

Bernard [56] studied the Angelica archangelica oil from France. Fruits of cultivated var. sativa, var. sativa growing wild and the population of $A a$ subsp. litoralis from the coast were compared. The dominant compound of the oil in the tested samples was $\beta$-phellandrene, whose concentration ranged from $64.9-65.8 \%$ in var. sativa, up to $76.0 \%$ in subsp. litoralis. The other main ingredient of the oil was $\alpha$-pinene. The composition and level of other compounds were substantially different. Essential oil composition of var. sativa consisted of more ingredients than subsp. litoralis.

\section{CHEMICAL CHARACTERISTICS OF COUMARINS OF ANGELICA}

Coumarins are one of the most characteristic and 
distinctive chemical markers for the genus Angelica and the Apiaceae family [60]. Coumarins are benzo$\alpha$-pyrone derivatives. They are also classified as phenylpropane derivatives due to their biogenetic origin and the presence of the basic $\mathrm{C} 6-\mathrm{C} 3$ skeleton in the lactone system [61]. As compounds with a lactone structure, they are biologically active compounds with very different properties depending on the type of compound. Therefore, knowledge of the composition of the raw material is important for therapeutic purposes. Among coumarins found in angelica, simple coumarins and furanocoumarins are most often identified and present in raw material. Simple coumarins are derivatives of coumarin, with substituents mainly in the C7, C6 and C3 position of the benzopyrone skeleton. Furanocoumarins (linear and angular) are compounds with an additional five-membered furan ring attached to the coumarin core at C6 and C7 or C7 and C8 [62]. Linear furanocoumarins such as 8-methoxypsoralen (xanthotoxin) and 5-methoxypsoralen (bergapten) have strong photosensitizing properties, which may cause skin irritation as well as abnormal pigmentation, itching and erythema [63]. Nevertheless, in adequate amounts the compounds are used for treatment of skin lesions (vitiligo and psoriasis) [64]. Many coumarins including phellopterin, imperatorin, osthole have a sedative effect on the central nervous system [11]. Dihydroxide furanocoumarins have a spasmolytic and vasodilating effect [65].

The basic method used to study coumarin compounds in plants is TLC and HPLC $[61,66,67]$. The HPLC-MS is used for the analysis of this group of compounds, as a faster and more efficient method, which enables identification of compounds that are otherwise difficult to distinguish [68]. Nowadays, extraction in the supercritical state SFE is more commonly used in isolation of natural substances rather than the traditional method of extraction with organic solvents or steam distillation [16].

So far, over 30 coumarin compounds were isolated and identified in the angelica plant, 27 of them were found in the root, 17 in fruit and 5 in leaves [69]. The main coumarins reported in the angelica root and fruit are listed in table 2 . The dominant ingredient found in raw materials was imperatorin [67]. However, there are several studies that have analyzed the intra-species diversity of $A$. archangelica in more detail. Separation of individual coumarins is not easy due to the large similarity of structure in this group of compounds [70]. Therefore, the most attention was paid to analytical techniques to optimize the methods of obtaining coumarins from the raw material.

\section{Root}

Angelica root contains from 0.001 to $0.008 \%$ of coumarin compounds [62]. In root extracts, mainly linear furanocoumarins have been isolated and identified, among others imperatorin, bergapten, isoimperatorin, isopimpinellin, oxypeucedanin, oxypeucedanin hydrate, and xanthotoxin. Mentioned substances were found in the root irrespectively of the origin of raw material. In the raw material simple coumarins - osthenol, osthole, ostruthol, umbelliferone as well as angular coumarins - angelicin and archangelicin are present. Differences concerning coumarin composition in the root analyzed by different scientists are compared in table 2.

Cisowski et al. [71] examined chloroform extracts of the root of $A$. archangelica - a commercial sample of raw material and $A a$ subsp. litoralis originating from the natural site in northern Poland (Mielno). In the tested samples of both taxa they identified 13 coumarins: imperatorin, bergapten, isoimperatorin, isopimpinellin, oxypeucedanin, oxypeucedanin hydrate, archangelicin, xanthotoxin, ostruthol, umbelliprenin, umbelliferone, osthenol and osthole.

Härmälä et al. [72] detected the presence of 15 coumarin compounds in the root of angelica. In addition to the above mentioned compounds, the new ingredients isolated and identified in the angelica root were as follows: psoralen, phellopterin, byakangelicin angelate, 2'-angeloyl-3'-isovaleryl vaginate and 8-[2-(3-methylbutroxy)-3-hydroxy-3methylbutoxy] psoralen.

Wszelaki et al. [73] conducted the survey of coumarins by HPLC-MS-DAD method in hexane extracts of angelica root grown in Poland. The TLC bioautography-guided fractionation and spectroscopic analysis enabled the isolation and identification of heraclenol-2'-O-angelate in root extracts.

Among 20 tested organic compounds used for extraction, chloroform was proven to be the most effective solvent for extraction of coumarins from plant material [72].

\section{Fruit}

The concentration of coumarins in angelica fruits reached up to $3.5 \%[76,77]$. Among known and available substrates, angelica fruit is one of the richer sources of furanocoumarins. The coumarin fraction in the fruit consisted mainly of imperatorin, isopimpinelin, phellopterin, bergapten, isoimperatorin, xanthotoxin $[70,73,78]$. The dominant 
Coumarin content in Angelica archangelica [\%]

Table 2.

\begin{tabular}{|c|c|c|c|c|c|c|c|c|c|c|c|c|c|c|c|c|}
\hline $\begin{array}{l}\text { Compound/ } \\
\text { References }\end{array}$ & $\begin{array}{l}\text { Root } \\
\text { [71] }\end{array}$ & {$[72]$} & {$[68]$} & {$[73]$} & {$[74]$} & $\begin{array}{c}\text { Fruit } \\
{[78]}\end{array}$ & {$[70]$} & [71] & [57] & {$[75]$} & [80] & {$[77]$} & {$[66]$} & [3] & {$[16]$} & [73] \\
\hline Osthenol & + & & + & + & & & & + & & & & & & & & \\
\hline Umbelliprenin & + & & & & & & & + & & & & 0.31 & & & & \\
\hline Umbelliferone & + & & + & & & + & & + & & & & & & & & \\
\hline Osthole & + & + & + & + & & & & + & & & & & & & & + \\
\hline Scopoletin & & & & & & & & & & & & & + & & & \\
\hline Angelicin & & & & & + & & & & & & & 0.01 & + & & & \\
\hline Archangelicin & + & + & & + & & & & + & & + & & & & & & + \\
\hline Bergapten & + & + & + & + & + & 0.33 & + & + & 0.29 & + & $0.16-0.56$ & 0.59 & + & $0.06-0.40$ & + & + \\
\hline Imperatorin & + & + & + & + & + & 1.31 & + & + & 2.44 & + & $0.96-2.57$ & 2.33 & + & $0.58-1.55$ & + & + \\
\hline Isoimperatorin & + & + & + & + & & & + & + & & + & & 0.04 & + & $0.03-0.62$ & + & + \\
\hline Isopimpinellin & + & + & + & + & & 0.12 & + & + & & & & & + & & + & + \\
\hline Oxypeucedanin & + & + & + & + & & & & + & & & & 0.13 & + & $0.00-0.64$ & & \\
\hline $\begin{array}{l}\text { Oxypeucedanin } \\
\text { hydrate }\end{array}$ & + & + & + & + & & & & + & & & & & & & & \\
\hline Xanthotoxin & + & + & + & + & + & 0.13 & & + & 0.25 & + & $0.09-0.51$ & 0.08 & + & $0.06-0.36$ & + & + \\
\hline Xanthotoxol & & & + & & & & & & & & & 0.01 & & & & \\
\hline Ostruthol & + & + & + & & & & & + & & & & & + & & & \\
\hline Psoralen & & + & + & & & & & & & & & 0.30 & & & & \\
\hline Phellopterin & & + & + & + & & 0.66 & + & & & + & & & & $0.11-0.75$ & & + \\
\hline Byakangelicin & & + & & + & + & & & & & & & & & & & \\
\hline $\begin{array}{l}\text { 2'-Angeloyl-3'- } \\
\text { isovaleryl vaginate }\end{array}$ & & + & & + & & & & & & & & & & & & \\
\hline $\begin{array}{l}\text { 8-[2-(3- } \\
\text { Methylbutroxy)-3- } \\
\text { hydroxy-3- } \\
\text { methylbutoxy] } \\
\text { psoralen }\end{array}$ & & + & & & & & & & & & & & & & & \\
\hline $\begin{array}{l}\text { Heraclenol-2'-O- } \\
\text { angelate }\end{array}$ & & & & + & & & & & & & & & & & & \\
\hline Pimpinellin & & & & & & & & & & & & & & & + & \\
\hline
\end{tabular}

ingredient was imperatorine, which constituted from 1.31 to $2.57 \%$. Further compounds are phellopterin $(0.66 \%)$ and bergapten $(0.33 \%)$ [78], bergapten $(0.29 \%)$ and xanthotoxin $(0.25 \%)$ [79] or bergapten (0.59\%) and umbelliprenin (0.31\%) [77] depending on the origin of the raw material. The imperatorine content was usually 2-4 times higher than the next compound. Research shows that imperatorine can constitute even over $80 \%$ of the furanocoumarins fraction in angelica fruit $[16,79]$.
The diversity of coumarins within the Angelica archangelica species was discussed by Sigurdsson et al. [3]. The fruit collected from 64 sites in Iceland was analyzed. Raw material from the south of country was rich in isoimperatorin and bergapten. Samples from the northern part of the country were distinguished by a high content of oxypeucedanin, which was often absent in samples from the south. Results of the study indicate that the level of furanocumarins and proportions of individual compounds 
Aa vary significantly depending on the geographical origin of the plants, which makes it difficult to classify plants into subspecies.

Wierzchowska-Renke et al. [80] compared the chemical composition of $A$. litoralis fruits from 9 natural sites from northern Poland. The content of sum of furanocoumarins in fruits ranged from 14.24 to $36.4 \mathrm{mg} / \mathrm{g}$. Fruits of plants originating from different sites differed in the concentration of the test compounds by more than double.

Modern analytical techniques have been tested in order to improve the isolation and identification of coumarins from angelica fruit. Wolski et al. [16] obtained a furanocoumarin complex from angelica fruits using supercritical extraction (SFE) on a preparative scale. The best results of furanocoumarin content were obtained in extraction conditions carried out for 10 hours at a temperature of $40^{\circ} \mathrm{C}$ and a pressure of 200 bar. Analysis of the composition and percentage of the main furanocoumarins in angelica fruits showed that imperatorin is the dominant ingredient and other substances such as isopimpinellin, xantotoxin and bergapten are also present in high concentrations.

The impact of different methods of extraction on furanocoumarins yield was tested by Waksmundzka-Hajnos et al. [78]. Samples were analyzed using the HPLC with extracts from angelica fruit obtained by: Soxhlet extraction, ultrasound-assisted extraction (USAE), microwave-assisted solvent extraction (basis) in open and closed systems, and accelerated solvent extraction (ASE). Among the methods tested, the highest yield of coumarins was obtained with the help of ASE method, using methanol (temperature $100-130^{\circ} \mathrm{C}$, time $10 \mathrm{~min}$.). The proportions of the main coumarins in individual extraction methods remained at a similar level.

An alternative to conventional methods for isolating furanocoumarin from fruit was proposed by Oniszczuk et al. [20]. The yield was prepared by matrix solid-phase dispersion (MSPD) method compared with ultrasonification with solid-phase extraction (USAE-SPE) and then HPLC analyses were performed. Research results indicate that the matrix solid-phase dispersion (MSPD) is an effective, simple and fast method suitable for the isolation of furanocoumarins from medicinal raw materials.

Sieniawska et al. [70] described a method of repeatedly developing HPTLC at a constant distance with a decreasing gradient of the developing system as the optimal procedure for analyzing the coumarin fraction in the angelica fruit extract. It can be used as a routine screening procedure for the detection and verification of coumarin compounds in the raw material.

\section{CONCLUSIONS}

A survey of the scientific literature indicates that composition of tested essential oils and profile of coumarin compounds in Angelica archangelica shows significant differences depending on the origin of the plant, which can have an impact on biological activity of the raw material.

Analysis of collected data shows similarity of both essential oil components and volatite substances present in extracts. Different techniques used for determinig coumarin components yielded comparable results.

Review of studies on angelica points at numerous chemical markers which can be used for identification and authentication of raw material. Moreover, they can also be helpful for chemotaxonomic studies to show both similarities and differences between samples.

Ethical approval: The conducted research is not related to either human or animal use.

Conflict of interest: Authors declare no conflict of interest.

\section{REFERENCES}

1. Crighton E, Mullaney I, Trengove R, Bunce M, Maker G. The application of metabolomics for herbal medicine pharmacovigilance: a case study on ginseng. Essays Biochem 2016; 60(5):429-435. doi: http://dx.doi.org/10.1042/EBC20160030

2. Heinrich M. Quality and safety of herbal medical products: regulation and the need for quality assurance along the value chains. Br J Clin Pharmacol 2015; 80(1):62-66. doi: http://dx.doi. org/10.1111/bcp.12586

3. Sigurdsson S, Jonsdottir S, Gudbjarnason S. Geographical variation of the furanocoumarin composition of the fruits of Icelandic Angelica archangelica. Z Naturforsch 2012; 67c:1-7. doi: http:// dx.doi.org/10.1515/znc-2012-1-201

4. Sarker SD, Nahar L. Natural Medicine: The Genus Angelica. Curr Med Chem 2004; 11(11):1479-1500. doi: http://dx.doi. 
org/10.2174/0929867043365189

5. Liao CY, Downie SR, Li Q, Yu Y, He X, Zhou B. New insights into the phylogeny of Angelica and its Allies (Apiaceae) with emphasis on East Asian species, inferred from nrDNA, cpDNA, and morphological evidence. Syst Bot 2013; 38(1):266-281. doi: http://dx.doi. org/10.1600/036364413X662060

6. Feng T, Downie S R, Yu Y, Zhang X, Chen W, He X, Liu S. Molecular systematics of Angelica and allied genera (Apiaceae) from the Hengduan Mountains of China based on nrDNA ITS sequences: phylogenetic affinities and biogeographic implications. J Plant Res 2009; 122(4):403-414. doi: http://dx.doi. org/10.1007/s10265-009-0238-4

7. Rautio AM, Akselsson Linkowski W, Östlund L. They followed the power of the plant: historical sami harvest and traditional ecological knowledge (Tek) of Angelica archangelica in Northern Fennoscandia. J Ethnobiol 2016; 36(3):617636. doi: http://dx.doi.org/10.2993/0278-077136.3.617

8. European Pharmacopoeia. $9^{\text {th }}$ Edition 9.0, 2016:1242, Supplement 9.8:1348.

9. Kumar D, Bhat ZA, Kumar V, Chashoo IA, Khan NA, Shah MY. Pharmacognostical and phytochemical evaluation of Angelica archangelica Linn. Int J Drug Dev \& Res 2011; 3(3):173-188. doi: http://dx.doi.org/10.13140/RG.2.2.33913.16488

10. Kelber O, Bauer L, Kubelka W. Phytotherapy in functional gastrointestinal disorders. Dig Dis 2017; 35:36-42. doi: http://dx.doi. org $/ 10.1159 / 000485489$

11. Skalicka-Woźniak K, Orhan IE, Cordell GA, Nabavi SM, Budzyńska B. Implication of coumarins towards central nervous system disorders. Pharmacol Res 2016; 103:188-203. doi: http://dx.doi. org/10.1016/j.phrs.2015.11.023

12. Kimura T, Takamatsu J. Ferulic acid and Angelica archangelica extracts in dementia: Effects on cognitive functions and behavioral and psychological symptoms of dementia. In: Martin CR, Preedy VR, eds. Diet and nutrition in dementia and cognitive decline. 2015:993-1001.

13. Kumar D, Bhat ZA, Shah MY. Anti-anxiety ac- tivity of successive extracts of Angelica archangelica Linn. on the elevated t-maze and forced swimming tests in rats. J Tradit Chin Med 2012; 32(3):423-429. doi: http://dx.doi.org/10.1016/ s0254-6272(13)60049-7

14. Fraternale D, Flamini G, Ricci D. Essential oil composition of Angelica archangelica L. (Apiaceae) roots and its antifungal activity against plant pathogenic fungi. Plant Biosyst 2014; 150(3):558563. doi: http://dx.doi.org/10.1080/11263504.201 4.988190

15. Wolski T, Najda A, Hołderna-Kędzia E. Zawartość i skład olejków eterycznych oraz ekstraktów otrzymanych z owoców niektórych roślin z rodziny Umbelliferae (Apiaceae), wraz ze wstępną oceną przeciwbakteryjną ekstraktów. Post Fitoter 2004; 3(13):119-125.

16. Wolski T, Ludwiczuk A, Kędzia B, HołdernaKędzia E. Preparatywna ekstrakcja gazami w stanie nadkrytycznym (SFE) zespołów furanokumarynowych oraz ocena ich aktywności przeciwgrzybiczej. Herba Pol 2000; 46 (4):332-339.

17. Oliveira CR, Spindola DG, Garcia DM et al. Medicinal properties of Angelica archangelica root extract: Cytotoxicity in breast cancer cells and its protective effects against in vivo tumor development. J Integr Med 2019; 17(2):132-140. doi: http://dx.doi.org/10.1016/j.joim.2019.02.001

18. Bruni R, Barreca D, Protti M, Brighenti V, Righetti L, Anceschi L et al. Botanical sources, chemistry, analysis, and biological activity of furanocoumarins of pharmaceutical interest. Molecules 2019; 24(11):2163. doi: http://dx.doi.org/10.3390/ molecules 24112163

19. Bryda J, Zagaja M, Szewczyk A, Andres-Mach M. Coumarins as potential supportive medication for the treatment of epilepsy. Acta Neurobiol Exp 2019; 79:126-132. doi: http://dx.doi. org/10.21307/ane-2019-011

20. Oniszczuk A, Skalicka-Woźniak K, Oniszczuk T, Waksmundzka-Hajnos M, Głowniak K. Matrix solid-phase dispersion versus ultrasound-assisted extraction with solid-phase extraction in the HPLC analysis of furanocoumarins from fruits of Archangelica officinalis Hoffm. J Braz Chem Soc 2014; 25(7):1166-1171. doi: http://dx.doi. org/10.5935/0103-5053.20140093 
21. Meusel H, Jäger EJ, Bräutigam $S$, Knapp HD, Rauschert S, Weinert E. Vergleichende Chorologie der zentraleuropäischen Flora. 3. G. Fischer Verlag, Jena 1992.

22. Thellung A. Umbelliferae. In: Hegi G, ed. Illustrierte Flora von Mitteleuropa. München 1926; 5(2):926-1537.

23. Ojala A. Variation of Angelica archangelica subsp. archangelica (Apiaceae) in northern Fennoscandia. 1. Variation in fruit morphology. Ann Bot Fennici 1984; 21:103-115.

24. Celka Z. Relicts of cultivation in the vascular flora of medieval West Slavic settlements and castles. Biodiv Res Conserv 2011; 22:1-110. doi: http:// dx.doi.org/10.2478/v10119-011-0011-0

25. Zając M, Zając A. Apophytes as invasive plants in the vegetation of Poland. Biodiv Res Conserv 2009; 15:35-40. doi: http://dx.doi.org/10.2478/ v10119-009-0015-1

26. Pyšek P, Sádlo J, Mandák B. Catalogue of alien plants of the Czech Republic. Preslia, Praha 2002; 74:97-186.

27. Keil P. Ökologie der gewässerbegleitenden Agriophyten Angelica archangelica ssp. litoralis, Bidens frondosa und Rorippa austriaca im Ruhrgebiet. [Ecology of the agriophytes Angelica archangelica ssp. litoralis, Bidens frondosa and Rorippa austriaca on river banks of the Ruhr region, Germany]. Dissertationes Botanicae, Band 321. J. Cramer Berlin-Stuttgart 1999.

28. Jackowiak B, Grabherr G. Zur Ausbreitung von Angelica archangelica L. an der Donau in Wien. Verh Zool-Bot Ges Österreich 1990; 127:113-122.

29. Jehlik V, Rostański K. Angelica archangelica subsp. litoralis auch in der Tschechoslowakei. Preslia, Praha 1975; 47(2):145-157.

30. Fosså O. Angelica: From Norwegian Mountains to the English Trifle. In: Hosking R. ed. Wild Food - Proceedings of the Oxford Symposium on Food and Cookery 2004. Totnes 2006:131-142.

31. Weinert E. Die taxonomische Stellung und das Areal von Angelica archangelica L. und A. lucida L. Feddes Repert 1973; 84(4):303-313. doi: http:// dx.doi.org/10.1002/fedr.19730840405
32. Singh R. Chemotaxonomy: a tool for plant classification. J Med Plants Stud 2016; 4(2):90-93.

33. Craft JD, Satyal P, Setzer WN. The chemotaxonomy of common sage (Salvia officinalis) based on the volatile constituents. Medicines 2017; 4(47):1-12. doi: http://dx.doi.org/10.3390/medicines 4030047

34. Sonboli A, Bahadori MB, DehghanH, Aarabi L, Savehdroudi P, Nekuei M et al. Chemotaxonomic importance of the essential-oil composition in two subspecies of Teucrium stocksianum Boiss. from Iran. Chem Biodivers 2013; 10(4):687-94. doi: http://dx.doi.org/10.1002/cbdv.201200088

35. Kim S, Kim KY, Han CS, Ki KS, Min KJ, Zhang X, Whang WK. Simultaneous analysis of six major compounds in Osterici Radix and Notopterygii Rhizoma et Radix by HPLC and discrimination of their origins from chemical fingerprint analysis. Archives of Pharmacal Research 2012; 35(4):691-699. doi: http://dx.doi.org/10.1007/ s12272-012-0413-3

36. Morsy NFS. Chemical structure, quality indices and bioactivity of essential oil constituents. In: El-Shemi HA (ed.). Active ingredients from aromatic and medicinal plants. 2017:175-206. doi: http://dx.doi.org/10.5772/66231

37. Williams C. Medicinal plants in Australia. Vol. 2. Gums, resins, tannin and essential oils, Australia 2011:174.

38. Forsén K. Aroma constituents of Angelica archangelica. Variation in the composition of the essential root oil of strains of var. norvegica and var. sativa. Rep Kev Subart Res Stat 1979; 15:1-7.

39. Tisserand R, Young R. Essential oil safety. $2^{\text {nd }}$ edition 2014:194.

40. Nivinskienė O, Butkienè R, Mockutė D. The chemical composition of the essential oil of Angelica archangelica L. roots growing wild in Lithuania. J Essent Oil Res 2005; 17(4):373-377. doi: http:// dx.doi.org/10.1080/10412905.2005.9698934

41. Doneanu C, Anitescu G. Supercritical carbon dioxide extraction of Angelica archangelica L. root oil. J Supercrit Fluid 1998; 12(1):59-67. doi: http:// dx.doi.org/10.1016/s0896-8446(97)00040-5 
42. Nykänen I, Nykänen L, Alkio M. Composition of Angelica root oils obtained by supercritical $\mathrm{CO}_{2}$ extraction and steam distillation. J Ess Oil Res 1991; 3(4):229-236. doi: http://dx.doi.org/10.108 0/10412905.1991.9697933

43. Taskinen J, Nykänen L. Chemical composition of angelica root oil. Acta Chem Scand B 1975; 29(7):757-764. doi: http://dx.doi.org/10.3891/ acta.chem.scand.29b-0757

44. Holm Y, Solberg S, Hiltunen R. Variation in Angelica archangelica root essential oils. Planta Med 2009; 75. doi: http://dx.doi. org/10.1055/s-0029-1234418

45. Ojala A. Huopalahti R, Nykänen A, Kallio H. Variation of Angelica archangelica subsp. archangelica (Apiaceae) in northern Fennoscandia. 5. Variation in composition of essential oil. Ann Bot Fennici 1986; 23:325-332.

46. Kerrola KM, Kallio HP. Extraction of volatile compounds of Angelica (Angelica archangelica L.) root by liquid carbon dioxide. J Agric Food Chem 1994; 42(10):2235-2245. doi: http://dx.doi. org/10.1021/jf00046a030

47. Galambosi B, Roitto M. Pohjoisessa kasvatettujen yrttien aromisuus. Maa- ja elintarviketalous [Aromas of herbs grown in the North]. Agric Food 2006; 84:31-40.

48. Sigurdsson S, Ögmundsdottir HM, Gudbjarnason $\mathrm{S}$. The cytotoxic effect of two chemotypes of essential oils from the fruits of Angelica archangelica L. Anitcancer Res 2005; 25:1877-1880.

49. Kerrola K, Galambosi B, Kallio H. Characterization of volatile composition and odor of angelica (Angelica archangelica subsp. archangelica L.) root extracts. J Agric Food Chem 1994; 42(9):19791988. doi: http://dx.doi.org/10.1021/jf00045a028

50. Aćimović MG, Pavlović S, Varga AO, Filipović VM, Cvetković MT, Stanković JM et al. Chemical composition and antibacterial activity of $A n-$ gelica archangelica root essential oil. Nat Prod Commun 2017; 12(2):205-206. doi: http://dx.doi. org/10.1177/1934578X1701200216

51. Nivinskienë O, Butkienë R, Mockutë D. Changes in the chemical composition of essential oil of Angelica archangelica L. roots during storage.
Chemija 2003; 14(1):52-56.

52. Pasqua G, Monacelli B, Silvestrini A, Manganaro R. In vitro root differentiation and essential-oil accumulation in Angelica archangelica. In Vitro Cell Dev Bio Plant 2001; 37(6):763-766. doi: http://dx.doi.org/10.1007/s11627-001-0126-7

53. Chalchat J-C, Garry R-P. Essential Oil of Angelica Roots (Angelica archangelica L.): optimization of distillation, location in plant and chemical composition. J Essent Oil Res 1997; 9(3):311-319. doi: http://dx.doi.org/10.1080/10412905.1997.10554 250

54. Holm Y, Vuorela P, Hiltunen R. Enantiomeric composition of monoterpene hydrocarbons in hexane extracts of Angelica archangelica L. roots and seeds. Flavour Fragr J 1997; 12(6):397-400.

55. Bernard C, Clair G. Essential oils of three Angelica L. species growing in France. Part I. Root oils. J Essent Oil Res 1997; 9(3):289-294. doi: http:// dx.doi.org/10.1080/10412905.1997.10554246

56. Bernard C. Essential oils of three Angelica L. species growing in France. Part II: Fruit oils. J Essent Oil Res 2001; 13(4):260-263. doi: http://dx.doi.or g/10.1080/10412905.2001.9699689

57. Gawdzik J, Mardarowicz M, Suprynowicz Z, Kawka S, Wolski T. Supercritical fluid extraction of essential oils from the fruits of Archangelica off. Hoffm. and their characterization by GC/MS. J High Resol Chromatogr 1996; 19(4):237-240. doi: http://dx.doi.org/10.1002/jhrc.1240190416

58. Wolski T, Najda A, Ludwiczuk A. The content and composition of essential oils and fatty acids obtained from the fruits of angelica (Archangelica officinalis Hoffm.). Herba Pol 2003; 49(3-4):151-156.

59. Nivinskiene O, Butkiene R, Mockute D. The seed (fruit) essential oils of Angelica archangelica L. growing wild in Lithuania. J Ess Oil Res 2007; 19(5):477--481. doi: http://dx.doi.org/10.1080/1 0412905.2007.9699957

60. Widelski J, Popova M, Graikou K, Glowniak K, Chinou I. Coumarins from Angelica lucida L. - antibacterial activities. Molecules 2009; 14(8):2729-2734. doi: http://dx.doi.org/10.3390/ molecules14082729 
61. Waksmundzka-Hajnos M, Hawrył MA. Application of TLC in the isolation and analysis of coumarins. In: Waksmundzka-Hajnos M, Sherma J, Kowalska T (eds.). Thin Layer Chromatography in Phytochemistry, 2008:366-375.

62. Wagner H, Bladt S, Zgainski EM. Coumarin Drugs. In: Plant Drug Analysis. Springer Verlag, Berlin-Heidelberg, 1984:125-147. doi: http:// dx.doi.org/10.1007/978-3-662-02398-3_7

63. EMEA. Reflection paper on the risk associated with furocoumarins contained in preparations of Angelica archangelica L. London, 31 October 2007, Doc Ref EMEA/HMPC/317913/2006

64. Conforti F, Marrelli M, Menichini F, Bonesi M, Statti G, Provenzano E, et al. Natural and synthetic furanocoumarins as treatment for vitiligo and psoriasis. Curr Drug Ther 2009; 4(1):38-58. doi: http://dx.doi.org/10.2174/157488509787081886

65. Najmanova I, Dosedel M, Hrdina R, Anzenbacher P, Filipsky T, Riha M, et al. Cardiovascular effects of coumarins besides their antioxidant activity. Curr Top Med Chem 2015; 15:830-849. doi: http://dx .doi.org/10.2174/1568026615666150220112437

66. Härmälä $P$, Vuorela $H$, Lehtonen $P$, Hiltunen R. Optimization of the high-performance liquid chromatography of coumarins in Angelica archangelica with reference to molecular structure. J Chromatogr A 1990; 507:367-380. doi: http:// dx.doi.org/10.1016/s0021-9673(01)84214-x

67. Sigurdsson S, Jonsdottir S, Gudbjarnason S. Geographical Variation of the furanocoumarin composition of the fruits of Icelandic Angelica archangelica. Z Naturforsch C 2012; 67(1-2):1-7. doi: http://dx.doi.org/10.1515/znc-2012-1-201

68. Eeva M, Rauha J-P, Vuorela P, Vuorela H. Computerassisted, high-performance liquid chromatography with mass spectrometric detection for the analysis of coumarins in Peucedanum palustre and Angelica archangelica. Phytochem Anal 2004; 15(3):167-174. doi: http://dx.doi.org/10.1002/pca.764

69. Ojala T. Biological screening of plant coumarins. Academic Dissertation. The Faculty of Science of the University of Helsinki 2001:17-19.

70. Sieniawska E, Baj T, Ulz Z, Głowniak K. Analysis of coumarin fraction from Angelica archangelica
L. fruits using multiple development HPTLC method. Farm Przegl Nauk 2011; 1:11-15.

71. Cisowski W, Głowniak K, Matysik G, Soczewiński E. Analiza frakcji kumarynowych z Angelica archangelica L. i Archangelica litoralis Fries. za pomocą wysokosprawnej chromatografii cienkowarstwowej (HPTLC). [Fractions Analysis from Angelica archangelica L and Archangelica litoralis Fries. by means of High Performance Thin-Layer Chromatography (HPTLC)]. Herba Pol 1987; 33(4):233-243.

72. Härmälä P, Vuorela $H$, Hiltunen R, Nyiredy S, Sticher O, Törnquist K et al. Strategy for the isolation and identification of coumarins with calcium antagonistic properties from the roots of Angelica archangelica. Phytochem Anal 1992; 3(1):42-48. doi: http://dx.doi.org/10.1002/pca.2800030108

73. Wszelaki N, Paradowska K, Jamróz MK, Granica S, Kiss AK. Bioactivity-guided fractionation for the butyrylcholinesterase inhibitory activity of furanocoumarins from Angelica archangelica L. roots and fruits. J Agric Food Chem 2011; 59(17):9186-9193. doi: http://dx.doi.org/10.1021/ jf201971s

74. Nemeth S, Pașca B, Teodorescu A, Coita I, Teaha D. Coumarins isolated from the dry roots of $A n$ gelica archangelica $\mathrm{L}$. and their antibacterial activity. Analele Universității din Oradea, Fascicula: Ecotoxicologie, Zootehnie şi Tehnologii de Industrie Alimntară 2015, 14(B):355-362.

75. Muller M, Byres M, Jaspars M, Kumarasamy $Y$, Middleton M, Nahar L et al. 2D NMR spectroscopic analyses of archangelicin from the seeds of Angelica archangelica. Acta Pharm 2004; 54(4):277-285.

76. Gawron A, Głowniak K. Cytostatic activity of coumarins in vitro. Planta Med 1987; 53(6):526-529. doi: http://dx.doi.org/10.1055/s-2006-962801

77. Herde A. Untersuchung der Cumarinmuster in Früchten ausgewählter Apiaceae. $\mathrm{PhD}$ thesis, University of Hamburg, Germany 2005.

78. Waksmundzka-Hajnos M, Petruczynik A, Dragan A, Wianowska D, Dawidowicz AL. Effect of extraction method on the yield of furanocoumarins from fruits of Archangelica officinalis Hoffm. Phytochem Anal 2004; 15:313-319. doi: 
http://dx.doi.org/10.1002/pca.784

79. Gawdzik J, Kawka S, Mardarowicz M, Suprynowicz Z, Wolski T. Carbon Dioxide Fractionated Supercritical Fluid Extraction of Furanocoumarins from the Fruits of Archangelica officinalis Hoffm.
Herba Pol 1996; 42(1):26-35.

80. Wierzchowska-Renke K, Zobel AM, Głowniak K. Volatile oil, furanocoumarins and some microelements content of Archangelica litoralis Fr Ann Acad Med Gedan 1996; 26:163-173. 